\title{
A (Im)Possibilidade da Clonagem Humana Frente à LEgislação Brasileira: uMa ANálise da Obra AdmiráVEL MUNDo Novo
}

\author{
Germano Schwartz ${ }^{(*)}$ \\ Elisana Schreiner ${ }^{(* *)}$
}

\section{RESUMO}

O presente artigo pretende demonstrar que o Direito pode abrir-se para as influências das demais ciências sociais, mediante uma nova visão desta ciência e da justiça, estudando o Direito com base na Literatura. Para tanto, o Movimento Direito e Literatura dividiu essa nova disciplina jurídica em três ramos: Direito da Literatura, Direito como Literatura e Direito na Literatura. Esse último será objeto do presente estudo, por meio da análise da obra Admirável Mundo Novo, do autor Aldous Huxley. Será investigada a (im)possibilidade da clonagem humana diante do atual ordenamento jurídico brasileiro.

\section{Palavras-chave}

Clonagem de Organismos; Ética; Legislação; Reprodução Assexuada.

\section{ABSTRACT}

This article intends to show that Law could open up to the influences of other social sciences, through a new vision of this science and of the

(*) Doutor em Direito pela Universidade do vale do Rio dos Sinos, professor do PPGD-ULBRA/Canoas, coordenador no Curso de Direito da Escola Superior de Administração, Direito e Economia, professor da Faculdade da Serra Gaúcha. E-mail: <germano.schwartz@ esade.edu.br>.

${ }^{* *}$ Bacharel em Ciências Jurídicas e Sociais pela Faculdade de Direito da Universidade de Passo Fundo. Recebido em 19.3.08. Aprovado em 15.5.08. 
justice. This paper studies Law based in Literature. For this, the Law and Literature Movement has divided this new discipline legal into three branches: right of literature, law as literature and law in Literature. The last branch will be object of this study which analyzes the work Brave New World, of Aldous Huxley. It investigates the (im)possibility of human cloning in face of current Brazilian law.

\section{Keywords}

Asexual Reproduction; Cloning Organism; Ethics; Legislation.

\section{INTRODUÇÃO}

O presente estudo demonstrará as relações existentes entre o Direito e a Literatura, por meio da análise de suas semelhanças e diferenças, enfocando os estudos do Movimento Law and Literature. Nesse contexto, serão destacados aspectos jurídicos abordados na obra literária "Admirável Mundo Novo", do autor Aldous Huxley, em especial a (im)possibilidade da clonagem de seres humanos frente à legislação brasileira.

É com base no Direito na Literatura que se pode demonstrar a forma como a ciência literária utiliza a ciência jurídica em suas obras, o que ocorre por exemplo, na obra "Admirável Mundo Novo". Nela, o autor descreve uma sociedade segura, estável e ideal, atingida por meio de avanços na área da biotecnologia como a produção em massa de seres humanos, mediante aplicação do Processo Bokanovsky e de técnicas como a hipnopedia, que possibilitaram a padronização de condutas e, portanto, o cumprimento da legislação, ou seja, segurança e estabilidade social e jurídica.

Por meio da análise de uma obra literária, pretende-se o aprimoramento do estudo jurídico, mediante sua atuação e interação com as demais ciências da sociedade, o que Ihe possibilitará uma conexão com a evolução social. Dessa forma, o sistema jurídico poderá avançar no mesmo ritmo que o meio social no qual se insere. Objetiva-se, ainda, a demonstração da (im)possibilidade da clonagem de seres humanos em vista do atual ordenamento jurídico brasileiro e, também, o estudo do Direito com base na Literatura mediante análise da obra "Admirável Mundo Novo", de Aldous Huxley.

O Law and Literature Movement dividiu seu estudo em três ramos: o Direito da Literatura, o Direito como Literatura e Direito na Literatura. No que tange ao Direito da Literatura, são abordados princípios e leis que protegem a ciência artística e as relações jurídicas que se formam por meio dessa atividade. Nesse ponto, destaca-se o disposto na Lei n. 9.610, de 19 de fevereiro de 1998, que disciplinou os Direitos do Autor no Brasil. 
Já, em relação ao Direito como Literatura, busca-se o entendimento de que peças, atos e procedimentos processuais sejam analisados e considerados espécies de obras literárias, por serem semelhantes à literatura narrativa, bem como pelo fato de que as duas ciências são comunicação via linguagem. Ambas descrevem a vida em sociedade, seja voltada à resolução de conflitos, no caso do Direito, seja destacando aspectos de seus pensamentos, sentimentos, expectativas e acontecimentos, de forma criativa e bela, no caso da Literatura. Além disso, destaca-se aspectos positivos do estudo conjunto dessas duas ciências no tocante à linguagem utilizada por seus operadores.

Finalmente, o Direito na Literatura estuda a maneira como obras literárias relatam e descrevem o mundo jurídico. Nesse sentido, são verificadas algumas obras e escritores literários que tratam de assuntos relacionados ao Direito. Assim, por meio dessa análise, será possível a compreensão da opinião da sociedade a respeito do Direito e de seus operadores, tendo em vista o fato de que obras literárias descrevem a visão social a respeito de diversos assuntos jurídicos, geralmente de maneira crítica.

Cabe mencionar que a obra literária analisada no presente estudo é um exemplo da abordagem de problemas jurídicos em produções da Literatura, uma vez que o autor Aldous Huxley descreve uma sociedade estável, segura e ideal, atingida graças a avançadas tecnologias sanitárias que possibilitaram a padronização de condutas e, portanto, estabilidade, segurança e respeito às leis.

Nesse sentido, o presente estudo investigará o Processo Bokanovsky e a sua (im)possibilidade no Direito Brasileiro. O Processo Bokanovsky era uma técnica fictícia de clonagem de seres humanos descrito em "Admirável Mundo Novo". O referido Processo será abordado estabelecendo suas semelhanças e diferenças com o procedimento de clonagem humana realizado nos dias de hoje. E, por fim, a verificação acerca da (im)possibilidade da realização de clonagem em humanos frente ao atual ordenamento jurídico brasileiro, enfatizando princípios constitucionais e bioéticos que tratam do assunto, bem como dispositivos da Lei n. 11.105, de 24 de março de 2005 - Lei de Biossegurança -, que disciplinou a questão da clonagem humana no Brasil.

Em face do referido contexto, neste estudo, serão apresentadas as diversas posições acerca do tema, enfocando-se os aspectos da legislação em vigor no Brasil, bem como os princípios constitucionais e bioéticos. Para tanto, relacionar-se-á a problemática jurídica com a Literatura.

\section{O PROCESSO BOKANOVSKY NO DIREITO BRASILEIRO}

\section{O Processo Bokanovsky e a fabricação de seres humanos}

Na obra "Admirável Mundo Novo", o autor Aldous Huxley descreve uma sociedade estável e ideal, atingida graças à padronização de condutas, 
mediante aplicação de técnicas de ensino durante o sono, a hipnopedia, da distribuição de um entorpecente, o soma, para toda a população, e a produção em massa de seres humanos clonados.

A fabricação de humanos era realizada no Centro de Incubação e Condicionamento de Londres Central, por meio do Processo Bokanovsky. Durante esse procedimento, as pessoas já eram produzidas de acordo com a classe social que ocupariam e eram divididas em Alfas, Betas, Gamas, Deltas e Ípsilons.

O Processo Bokanovsky, conforme explicação do Diretor de Incubação e Condicionamento, "[...] consiste essencialmente numa série de interrupções do desenvolvimento. Nós detemos o crescimento normal e, paradoxalmente, o ovo reage germinado em múltiplos brotos"(1).

Nesse sentido, para a aplicação desse processo, era necessária a conservação do ovário em laboratório, seccionado no estado vivo e em pleno desenvolvimento. Além disso, a fecundação, a manipulação e o desenvolvimento de embriões eram realizados laboratorialmente até o nascimento da criança. O método de conservação de embriões em incubadoras após a fecundação até o nascimento era aplicado para Alfas e Betas, visto que não eram submetidos à bokanovskização, por isso faziam parte das classes sociais dominantes. Já as castas inferiores, os Gamas, os Deltas e os Ípsilons, antes dessa conservação, eram submetidos ao Processo Bokanovsky.

É importante ressaltar o método de procedimento da bokanovskização conforme descrição do Diretor do Centro de Incubação e Condicionamento, no livro:

Um ovo, um embrião, um adulto - é o normal. Mas um ovo bokanovskizado tem a propriedade de germinar, proliferar, dividir-se: de oito a noventa e seis germes, e cada um destes se tornará um embrião perfeitamente formado, e cada embrião, um adulto completo. Assim se consegue fazer crescerem noventa e seis seres humanos em lugar de um só, como no passado. Progresso.(2)

Portanto, o Processo Bokanovsky, um dos principais instrumentos da estabilidade social, era responsável pela produção de inúmeros gêmeos idênticos, com a utilização de apenas um ovo, o que possibilitava a uniformização de homens e mulheres e o controle de seus atributos físicos e mentais, por meio da manipulação genética.

Os ovos bokanovskizados eram submetidos a uma exposição de oito minutos aos raios $X$ duros, que possibilitavam a sua divisão em dois, quatro ou oito brotos. Na seqüência, passavam por uma fase de desenvolvimento

(1) HUXLEY, Aldous. Admirável mundo novo. 2. ed. São Paulo: Globo, 2003. p. 13.

(2) Id. Ibid., p. 12-13. 
em incubadoras durante dois dias. Em ato contínuo, eram submetidos ao frio e à interrupção do crescimento, pois se dividiam, mais uma vez, em dois, quatro ou oito. E, finalmente, eram submetidos a uma dose quase mortal de álcool para dividirem-se novamente ${ }^{(3)}$.

Nesse contexto, observa-se que o ovo inicial era dividido em inúmeros brotos, de oito a noventa e seis. Após essas operações, os brotos poderiam se desenvolver em suas incubadoras até seu nascimento. Essas incubadoras eram desenvolvidas com mecanismos que forneciam oxigênio, pseudo-sangue, movimentação e nutrientes necessários ao desenvolvimento do feto.

Além disso, durante seu desenvolvimento, os brotos já eram condicionados a suportar as dificuldades de suas futuras profissões como o frio, o calor ou o desconforto físico, para que pudessem apreciar tais situações e, mais tarde, viverem bem e felizes. "[...] o segredo da felicidade e da virtude: amarmos o que somos obrigados a fazer. Tal é a finalidade de todo o condicionamento: fazer as pessoas amarem o destino social de que não podem escapar."(4)

Em face desse contexto, percebe-se que a fabricação de seres humanos e o seu condicionamento psicológico garantiam estabilidade e segurança social, haja vista a prédeterminação das atitudes, pensamentos, gostos, profissões, modo de se vestir de todas as pessoas, tudo de acordo com a sua classe social, o que garantia que não haveria descontentamento social e, por conseqüência, instabilidade.

É o ovo bokanovskizado. Deles seriam gerados homens e mulheres padronizados, em grupos uniformes. Todos passariam por um processo de condicionamento feito por uma técnica denominada hipnopedia. Seriam anos escutando e aprendendo lições de convivência em sociedade. Logo, não haveria questionamentos a respeito do cumprimento das leis. Elas seriam cumpridas. Com isso, haveria estabilidade social, que, segundo, o mesmo Diretor anteriormente citado, é o segredo da felicidade e da virtude. ${ }^{(5)}$

Com efeito, o Processo Bokanovsky é o principal instrumento da estabilidade social do Admirável Mundo Novo. Hodiernamente, pode-se comparar o referido processo com os métodos de clonagem humana. Nesse contexto, cabe ressaltar que o termo clone é derivado do grego klon, que significa broto. O clone é considerado um organismo geneticamente idêntico, obtido de forma assexuada, e derivado de um mesmo indivíduo.

Nessa linha de pesquisa, destaque-se que o assunto tomou repercussão mundial em 1997, quando o cientista escocês lan Wilmut, apresentou o

(3) HUXLEY, Aldous, op. cit. p. 13.

(4) Id. Ibid., p. 24-25.

(5) SCHWARTZ, Germano. Um admirável novo direito: autopoiese, risco e altas tecnologias sanitárias. [S.I.:s.n.], 2006. p. 2. 
primeiro clone de animal superior, gerado de modo assexuado, a ovelha Dolly, produzida a partir de glândulas mamárias de uma ovelha de seis anos. O núcleo dessas células germinativas foi implantado no óvulo de outra oveIha, do qual se extraíra o núcleo. O embrião foi implantado no útero de uma terceira ovelha, que gestou Dolly, geneticamente igual à primeira ovelha.

A partir de então, o tema passou a ser alvo de discussões ético-acadêmicas nas mais diversas áreas. É imperioso referir também que o procedimento da clonagem consiste na retirada do núcleo de um óvulo não fecundado, o qual é substituído pelo núcleo de uma célula não sexual de um homem ou de uma mulher adulta. Na seqüência, essa célula-ovo será implantada no útero de uma mulher, que pode ser uma mãe de aluguel. Esse método de reprodução assexuada permite a criação indivíduos clonados com os mesmos caracteres genotípicos daquele que doou o núcleo da célula somática.

Para obter um clone, os cientistas retiram o material genético das células do animal a ser clonado e inserem esse material numa célula-ovo da qual o próprio material genético fora anteriormente removido. A célula-ovo modificada é implantada no útero de uma mãe de aluguel. $O$ indivíduo resultante desse procedimento é geneticamente idêntico ao doador do material genético. Desde a clonagem do primeiro mamífero - a ovelha Dolly, em 1997 - já se produziram clones de diversas espécies, entre elas camundongos, bovinos, suínos e caprinos. [...] $]^{(6)}$

Além disso, é importante mencionar que a clonagem pode ser feita de duas formas: a primeira consiste na separação das células de um embrião que já tinha iniciado seu processo de multiplicação celular; a segunda consiste na substituição do núcleo de um óvulo por outro de uma célula de um indivíduo já existente ${ }^{(7)}$. Podem-se clonar células, genes, tecidos, plantas, órgãos e indivíduos completos. "[...] é um método de reprodução normal para muitos seres, como as bactérias, seres unicelulares que nascem como clones, ou seja, como cópias genéticas perfeitas das mães, que simplesmente se duplicam e se dividem em duas."(8)

Ressalte-se, ainda, que a clonagem humana pode possuir finalidades diversas, reprodutiva ou terapêutica. Assim, por meio da clonagem reprodutiva, busca-se a produção de um indivíduo geneticamente idêntico ao doador da célula. Por outro lado, na clonagem terapêutica, pretende-se a produção de uma célula embrionária, para ser utilizada terapeuticamente pelo doador.

(6) ENCICLOPÉDIA Barsa. Ciência e futuro 2004. São Paulo: Barsa Planeta Internacional, 2004. p. 214.

(7) SÉGUIN, Elida. Biodireito. Rio de Janeiro: Lumen Juris, 2005. p. 94.

(8) BARBOZA, Heloisa Helena. Clonagem Humana: uma questão em aberto. In: SARMENTO, Daniel; PIOVESAN, Flávia (Coord.). Nos limites da vida: aborto, clonagem humana e eutanásia sob a perspectiva dos direitos humanos. Rio de Janeiro: Lumen Juris, 2007. p. 195. 
A clonagem terapêutica é realizada utilizando-se células sadias de um doador que sofre de uma doença degenerativa, como a diabetes ou o Mal de Alzheimer, por exemplo. Nesse caso, o embrião é cultivado em uma linhagem celular embrionária tronco, imortalizando suas células. As células-tronco embrionárias podem ser quimicamente diferenciadas em outras células para sua utilização terapêutica(9).

Essa forma de clonagem é condenada por muitos religiosos e laicos, em razão da destruição do embrião. A clonagem reprodutiva também não é aceita, em função de questões éticas e religiosas, como o direito à dignidade e individualidade da pessoa humana, bem como pelos diversos problemas no processo de reprodução como o desenvolvimento de anomalias no feto.

A explicação dos cientistas para os problemas apresentados pelos organismos clonados é de que seus genes não são corretamente ativados, visto que, no processo de clonagem, não ocorre a fusão de material genético de células sexuais femininas e masculinas, as quais possuem DNA propriamente impresso, ou seja, a dificuldade estaria no processo de "impressão genômica"(10).

[...] A técnica, porém, ainda é extremamente ineficiente, sendo inaceitavelmente baixa a média de sucesso, cerca de $2 \%$, em trabalhos publicados sobre clonagem de bovinos, ovelhas, porcos e ratos. Ressalte-se a incerteza de que esta taxa seja real, pois os experimentos que falham não são divulgados. A maioria dos filhotes nasce com até o dobro do peso normal, o que pode acarretar complicações respiratórias e cardiovasculares. Muitos nascem com deformidades, como vacas com cabeças e focinhos achatados, e não sobrevivem. Há riscos sérios também para as fêmeas que recebem os embriões, que podem inchar a ponto de estourar os músculos do abdome. O cordão umbilical e a placenta costumam crescer de maneira anormal. Outro problema a ser superado é o envelhecimento precoce do clone e encolhimentos dos telômeros, referente às estruturas cromossômicas que se desgastam à medida que a célula se divide e envelhece. ${ }^{(11)}$

Cabe mencionar que o clone possui apenas o mesmo patrimônio genético e não se trata de uma cópia do original, visto que o ser humano é constituído por um genótipo e um fenótipo (ambiente onde vive). Portanto, se o ambiente de vida do clone e de seu original forem divergentes, eles sofrerão influências ambientais diversas e possuirão diferenças fenotípicas, uma vez que o desenvolvimento psicológico, cultural e as experiências do clone farão com que sua personalidade seja diferente de seu original.

(9) BARBOZA, Heloisa Helena, op. cit., p. 196.

(10) Id. Ibid., p. 97.

(11) SÉGUIN, Elida, op. cit., p. 97. 
[...] se hoje criássemos por clonagem cinco ou dez Picassos, Madames Curie ou Sócrates obteríamos novamente Picasso, Madame Curie ou Sócrates pois o contexto familiar, cultural, político, económico, social, etc. seria outro. Se é certo que por um lado, a carga genética de um indivíduo é fundamental, por outro lado não podemos descurar o contributo essencial fornecido pelo meio. [...] Assim sendo, para "reproduzir" este contexto seria necessário "clonar", também, todos os outros indivíduos que dele faziam parte e que poderiam influenciar os clones de Picasso, Madame Curie ou Sócrates?! ... Não seria portanto uma fotocópia milimétrica, mas consubstanciaria, sem dúvida, a reprodução de seres com as mesmas características. ${ }^{(12)}$

No entanto, ressalte-se que, no "Admirável Mundo Novo", as pessoas viviam em ambientes idênticos e todas eram submetidas às mesmas técnicas de hipnopedia, bokanovskização e consumo de soma. Assim, pode-se afirmar que, no "Admirável Mundo Novo", diferentemente da sociedade atual, os clones possuíam genótipo e fenótipo idênticos, sendo literalmente cópias uns dos outros.

Portanto, feitas algumas explicações acerca do método de reprodução humana realizado pelo Processo Bokanovsky e dos procedimentos de clonagem de seres humanos em desenvolvimento nos dias de hoje, serão apresentados, na seqüência, aspectos da legislação estrangeira sobre a (im)possibilidade dessas formas de clonagem.

\section{A clonagem de seres humanos frente à legislação brasileira}

Finalmente, será analisada a (im)possibilidade da adoção do Processo Bokanovsky, isto é de técnicas de clonagem de seres humanos, diante dos princípios bioéticos e constitucionais brasileiros, bem como em relação à legislação do Brasil, especialmente, após a promulgação da Lei n. 11.105/05 - Lei de Biossegurança.

Nesse sentido, primeiramente, é importante fazer referência aos fundamentos bioéticos consagrados no Relatório de Belmont, o qual estabelece os princípios do respeito pela pessoa, da beneficência e da justiça, que devem ser observados na realização de qualquer pesquisa científica com seres humanos.

O já referido relatório Belmont, que estabeleceu as bases para a adequação ética nos Estados Unidos da América, denominava esse princípio como princípio do respeito às pessoas. Nessa perspectiva,

(12) BARBAS, Stela Marcos de Almeida Neves. Direito ao patrimônio genético. Coimbra: Almedina, 1998. p. 196. 
propunha que a autonomia incorpora, pelo menos, duas convicções éticas: a primeira, que os indivíduos devem ser tratados como agentes autônomos e a segunda, que as pessoas com autonomia reduzida devem ser protegidas. Uma pessoa autônoma é um indivíduo capaz de deliberar sobre seus objetivos pessoais, tem autodeterminação para agir com base em seus julgamentos. Em contrapartida, nem todas as pessoas têm a capacidade de se autodeterminar, já que a incapacidade mental, assim como a institucionalização dos prisioneiros, limitam a autonomia. Portanto, é evidente que tal princípio não pode ser aplicado em pacientes dementes ou psicóticos ou com incapacidade de expressar o próprio consentimento, como nos casos de estado de coma ou menoridade absoluta etc. ressalta-se que, ainda assim, esses indivíduos continuam a merecer o respeito que se deve a todas as pessoas. ${ }^{(13)}$

No que se refere ao princípio da beneficência, estabelece ele que, para a adoção de uma postura ética na realização de pesquisas com seres humanos, os cientistas devem buscar o máximo de benefícios e o mínimo de prejuízos à raça humana. Muitas vezes, esse princípio é considerado uma determinação de não-maleficência às pessoas. Assim, os riscos da pesquisa devem ser mínimos se comparados com seus avanços positivos.

O terceiro princípio bioético, que deve ser observado na realização de pesquisas sobre clonagem humana, é o da justiça, que determina que todas as pessoas sejam tratadas de modo isonômico. Assim, cada pessoa deve ser tratada com o que é ético e normalmente adequado, deve-se dar a cada um o que lhe é devido. Esse princípio exige que seja realizada uma distribuição equânime dos ônus e dos benefícios da pesquisa - justiça distributiva ${ }^{(14)}$.

Nesse contexto, verifica-se que, em relação aos princípios bioéticos, a principal preocupação com os procedimentos de clonagem humana reprodutiva, é a possível criação de distinções entre seres humanos: uns com carga genética própria e outros copiados geneticamente daqueles.

No caso da clonagem terapêutica, a polêmica gira em torno da dúvida se os benefícios à saúde de pessoas que sofrem de doenças degenerativas são mais importantes do que a proteção da vida dos embriões utilizados nesse procedimento. Nessa hipótese, discute-se qual o momento de início da vida, destacando-se que alguns defendem-no desde a nidação; outros afirmam que já começa com a fecundação, ou quando o feto possui capacidade de existir sem a mãe, o que aconteceria entre a 24a e a $26^{\underline{a}}$ semanas de gestação, segundo explicação médica, ou, ainda, após a formação do sistema nervoso central.

(13) RODRIGUES, Hugo Thamir. A aplicação dos princípios da bioética nas técnicas de reprodução medicamente assistida. In: RODRIGUES, Hugo Thamir (Coord.). Direito constitucional \& políticas públicas. Porto Alegre: Imprensa Livre, 2005. p. 35-36.

(14) PESSINI, Leo; BARCHIFONTAINE, Christian de Paul de. Problemas atuais de bioética. 6. ed. São Paulo: Loyola, 2002. p. 143. 
Além disso, no âmbito brasileiro, as pesquisas voltadas à manipulação genética humana devem observar os valores consagrados na Carta Magna de 1988, como o princípio da dignidade da pessoa humana (art. 1ㅜㄹ inciso III)(15), o direito à vida (art. 5을 caput) e a integridade física e moral e o direito à saúde (art. 196) ${ }^{(16)}$, bem como a preservação da diversidade e integridade do patrimônio genético do País (art. 225, § 1ํㅡㄹ incisos II e V) ${ }^{(17)}$.

No que tange ao princípio da dignidade da pessoa humana, Sarlet entende que:

A dignidade da pessoa humana engloba necessariamente respeito e proteção da integridade física e emocional (psíquica) em geral da pessoa, do que decorrem, por exemplo, a proibição da pena de morte, da tortura e da aplicação de penas corporais bem como a utilização da pessoa para experiências científicas. ${ }^{(18)}$

Assim, o princípio em análise, estabelece que cada ser humano deva ser respeitado enquanto pessoa, sendo necessário se evitarem a instrumentalização e a coisificação do ser humano, por meio da aplicação de técnicas de clonagem reprodutiva. No entanto, pode-se admitir, em alguns casos, a relativização da dignidade de uma pessoa, em detrimento da dignidade de todos os seres humanos, o que pode ocorrer, por exemplo, no caso da clonagem terapêutica.

No que se refere ao direito constitucional à vida, a questão da clonagem humana reprodutiva é condenada por grande parte dos bioeticistas e juristas, principalmente pelo fato de que um número considerável de experimentos realizados com animais demonstrou ineficácia. Cabe ressaltar que até o nascimento da ovelha Dolly foram realizadas 277 tentativas.

Já, em relação à clonagem terapêutica, a controvérsia é maior, em virtude do descarte do embrião para a obtenção de células-tronco. Nesse contexto, travam-se discussões acerca do exato momento em que se inicia a vida e, por outro lado, os benefícios que essas células-tronco podem proporcionar a pessoas portadoras de enfermidades neuromusculares.

(15) "Art. 1ํ A República Federativa do Brasil, formada pela união indissolúvel dos Estados e Municípios e do Distrito Federal, constitui-se em Estado democrático de direito e tem como fundamentos: [...] III - a dignidade da pessoa humana"; [...]

(16) "Art. 196. A saúde é direito de todos e dever do Estado, garantido mediante políticas sociais e econômicas que visem à redução do risco de doença e de outros agravos e ao acesso universal e igualitário às ações e serviços para sua promoção, proteção e recuperação".

(17) "Art. 225. [...] § 1ํ Para assegurar a efetividade desse direito, incumbe ao poder público: [...] II - preservar a diversidade e a integridade do patrimônio genético do País e fiscalizar as entidades dedicadas à pesquisa e manipulação de material genético; [...] V - controlar a produção, a comercialização e o emprego de técnicas, métodos e substâncias que comportem risco para a vida, a qualidade de vida e o meio ambiente"; [...].

(18) SARLET, Ingo Wolfgang. A eficácia dos direitos fundamentais. 2. ed. Porto Alegre: Ed. Livraria do Advogado, 2001. p. 89. 
Nesse sentido, o desenvolvimento de técnicas de clonagem com fins terapêuticos seria uma nova alternativa de garantia do direito à saúde, assegurado pela Constituição Federal, em seu art. 196. O direito à saúde, por estar positivado na lei maior do Estado, é reconhecido como direito social de toda população, cabendo ao Estado adotar políticas públicas que dêem suporte para efetivação desse direito.

A Constituição de 1988 inovou ao estabelecer a saúde como direito de todos e dever do Estado (art. 196), e ao sinalizar que tipo de saúde deve ser possibilitada aos cidadãos brasileiros e aos estrangeiros residentes no país (Dallari, 1995). Esse é o sentido das expressões "redução do risco de doença", "promoção", "proteção" e "recuperação" contidas no dispositivo constitucional anteriormente referido. Quando fala em "recuperação", a CF/88 está conectada ao que se convencionou chamar de saúde "curativa"; os termos "redução do risco de doença" e "proteção" estão claramente ligados à saúde "preventiva", e a "promoção" é a qualidade de vida, posteriormente explicitada pelo art. 225 da Carta Magna(19).

Portanto, o direito à saúde deve ser assegurado pelo Poder Público como direito fundamental que é, inclusive, mediante adoção de políticas públicas com essa finalidade. Nesse contexto, a realização de tratamentos com células-tronco para doenças degenerativas como o Mal de Alzheimer e de Parkinson, a cegueira, o câncer e a diabetes pode ser uma forma de garantir o direito à saúde e à vida aos portadores dessas enfermidades.

Por outro lado, a clonagem com fins reprodutivos seria uma afronta ao direito da pessoa humana à sua integridade física e moral, bem como à sua individualidade, pelo fato de que seria criado outro ser humano com a mesma carga genética do doador da célula, sendo o clone considerado por muitos uma cópia do indivíduo clonado.

"Para o grupo e para a espécie o que confere a um indivíduo o seu valor genético não é só a qualidade dos genes em si, mas, também, o facto de ele não ter o mesmo conjunto de genes que os outros, a circunstância de ser único e irrepetível."(20) Por conseguinte, o fato de não existir homogeneidade na Humanidade e de cada pessoa possuir sua identidade é o que garante a dignidade e a liberdade de todos e de cada um.

Nessa direção, o que assegura a riqueza de um país, como o Brasil, seria justamente a diversificação humana, a identidade de cada espécie e a mistura de raças, tendo em vista que todo ser humano é único e irrepetível. Nesse contexto, a tentativa de homogeneização da sociedade, como ocor-

(19) SCHWARTZ, Germano. Direito à saúde: efetivação em uma perspectiva sistêmica. Porto Alegre: Livraria do Advogado, 2001. p. 27.

(20) BARBAS, Stela Marcos de Almeida Neves, op. cit., p. 197. 
reu no "Admirável Mundo Novo", é ineficaz e acabaria com a individualidade de cada pessoa, visto que a identidade genética expressa a dignidade própria de cada um.

Em face desse contexto, verifica-se que, pelo simples fato de a Carta Magna determinar que o Poder Público deve preservar a diversidade e integridade do patrimônio genético do País, é impossível admitir-se qualquer técnica de clonagem reprodutiva, uma vez que essa prática agride a diversidade genômica das pessoas, por criar seres humanos idênticos sob o ponto de vista genético. Além disso, deve garantir o controle do emprego de qualquer técnica que possa causar risco à vida.

Nessa mesma linha de raciocínio, é o que determina a Lei n. 11.105, de 24 de março de 2005, denominada Lei de Biossegurança, em seu art. 6º, inciso $\mathrm{IV}^{(21)}$, que proíbe a clonagem humana. A referida lei, no art. $3^{\circ}$, inciso VII, considera clonagem como "o processo de reprodução assexuada, produzida artificialmente, baseada em um único patrimônio genético, com ou sem técnicas de engenharia genética". O Decreto n. 5.591, de 22 de novembro de 2005, que regulamentou a lei supramencionada, manteve o conceito de clonagem, em seu art. $3^{\circ}$, inciso $\mathrm{XI}^{(22)}$.

Nessa linha de raciocínio, o art. 3ㅜㅗ inciso IX, da Lei de Biossegurança, define o que é clonagem para fins reprodutivos - "clonagem com a finalidade de obtenção de um indivíduo" - , no inciso X, do mesmo artigo, o que é clonagem terapêutica - "clonagem com a finalidade de produção de célulastronco embrionárias para utilização terapêutica” - e, por fim, o inciso XI, do referido artigo, esclarece o que são células-tronco embrionárias ${ }^{(23)}$ - "células de embrião que apresentam a capacidade de se transformar em células de qualquer tecido de um organismo".

Pouco tempo após um óvulo ser fecundado por um espermatozóide, forma-se um agrupamento de cerca de cem células, o blastocisto, o qual, futuramente, dará origem a todos os tecidos do embrião, como fígado, pulmão, rins e coração. Estas células que compõem o embrião em seu estágio inicial têm um nome: células-tronco embrionárias. As células-tronco têm a característica de se transformar em qualquer outra célula ou tecido do organismo(24).

(21) "Art. 6‥ Fica proibido: [...] IV - clonagem humana"; [...]

(22) Art. 3‥ Para os efeitos deste Decreto, considera-se: [...] XI - clonagem: processo de reprodução assexuada, produzida artificialmente, baseada em um único patrimônio genético, com ou sem utilização de técnicas de engenharia genética"; [...].

(23) Vide art. 3ำ, inciso XII, do Decreto n. 5.591/2005 - Art. 3‥ Para os efeitos deste Decreto, considera-se: [...] XII - células-tronco embrionárias: células de embrião que apresentam a capacidade de se transformar em células de qualquer tecido de um organismo; [...].

(24) DINIZ, Maria Helena. O Estado atual do biodireito. 3. ed. São Paulo: Saraiva, 2006. p. 514. 
De outro modo, o art. $5^{\circ}$ da Lei de Biossegurança(25) assegura a permissão da utilização de células-tronco embrionárias obtidas de embriões humanos produzidos por fertilização in vitro e não utilizados nesse procedimento, desde que, com finalidades de pesquisa e terapia. O referido dispositivo legal exige que os embriões sejam inviáveis, ou congelados há três anos ou mais, na data da publicação da lei, ou se já congelados nessa data, depois de completarem três anos, contados a partir da data de congelamento.

Portanto, os embriões utilizados em pesquisas ou terapias com células-tronco devem preencher todos os requisitos exigidos pelo artigo supramencionado, que são a inviabilidade e o congelamento há mais de três anos. Cabe referir que o art. $3^{\circ}$, inciso XIII, do Decreto n. 5.591/05, definiu embriões inviáveis como sendo aqueles com alterações genéticas comprovadas por diagnóstico pré-implantacional, com alterações morfológicas que comprometam o pleno desenvolvimento do embrião, ou que tiveram seu desenvolvimento interrompido por ausência espontânea de clivagem, após período superior a vinte e quatro horas a partir da fertilização in vitro.

O Decreto n. 5.591/05 introduziu a expressão "embriões congelados disponíveis", sendo tais os que tivessem sido congelados até 28 de março de 2005 - data de publicação da Lei de Biossegurança - , após completarem 3 anos da data de seu congelamento. $O$ art. 63 do Decreto(26) permite a utilização de embriões inviáveis ou congelados disponíveis para obtenção de células-tronco, com finalidade de terapia e pesquisa.

Embora a clonagem tenha sido proibida pela Lei de Biossegurança, a utilização de células-tronco embrionárias é permitida no Brasil, desde que obtida de embriões excedentes das técnicas de fertilização in vitro, inviáveis ou congelados há mais de três anos. Desta forma, um dos maiores objetivos da clonagem terapêutica - a produção de órgãos para transplantes ou a recomposição destes a partir de células-tronco — ainda pode ser alcançado ${ }^{(27)}$.

No entanto, mesmo que a Lei de Biossegurança tenha autorizado a terapia e a pesquisa com células-tronco embrionárias, a questão ainda não possui entendimento pacífico, visto que a discussão ético-jurídico se man-

(25) "Art. 5․ É permitida, para fins de pesquisa e terapia, a utilização de células-tronco embrionárias obtidas de embriões humanos produzidos por fertilização in vitro e não utilizados no respectivo procedimento, atendidas as seguintes condições: I - sejam embriões inviáveis; ou II - sejam embriões congelados há 3 (três) anos ou mais, na data da publicação desta Lei, ou que, já congelados na data da publicação desta Lei, depois de completarem 3 (três) anos, contados a partir da data de congelamento".

(26) "Art. 63. É permitida, para fins de pesquisa e terapia, a utilização de células-tronco embrionárias obtidas de embriões humanos produzidos por fertilização in vitro e não utilizados no respectivo procedimento, atendidas as seguintes condições: I - sejam embriões inviáveis; ou II - sejam embriões congelados disponíveis".

(27) SÁ, Maria de Fátima Freire de; NAVES, Bruno Torquato de Oliveira. Clonagem humana. In: SARMENTO, Daniel; PIOVESAN, Flávia (Coord.), op. cit., p. 271. 
tém em relação à destruição do embrião, para retirada da célula-tronco. Por tal motivo, o art. 5ำ dessa lei é objeto da Ação Direta de Inconstitucionalidade - ADIn n. 3510, de 30 de maio de 2005, proposta pelo Procurador-Geral da República.

A ação supramencionada foi proposta contra a íntegra do art. 5ำ da Lei n. 11.105/05, insurgindo-se contra a permissão da utilização, para pesquisa e terapia de células-tronco obtidas de embriões humanos. A tese central volta-se contra a destruição do embrião, uma vez que o autor da ação sustenta que a vida se inicia a partir da fecundação, violando-se, assim, preceitos constitucionais do direito à vida e ao princípio da dignidade da pessoa humana, na prática de procedimentos para obtenção de células-tronco.

Portanto, o cerne do debate envolve questões bioéticas e jurídicas, especialmente em face do direito à identidade, dignidade da pessoa humana e diversidade biológica do País, em contraponto ao direito à reprodução, no caso da clonagem reprodutiva. Já a clonagem terapêutica coloca em conflito o direito fundamental à vida e o direito à saúde.

É importante destacar que o art. 6ํ, da Lei de Biossegurança, não estabeleceu distinção entre as formas de clonagem, pois proibiu a clonagem humana de maneira genérica. Da mesma forma, o art. 26, da mencionada Lei ${ }^{(28)}$, definiu como crime a realização de clonagem humana, punível com pena de reclusão, de 2 a 5 anos, e multa. Já o art. 69, inciso XII, do Decreto $\mathrm{n}$. $5.591 / 05^{(29)}$ considera infração administrativa toda ação ou omissão que viole as regras da Lei n. 11.105/05, em especial a realização de clonagem humana.

Existe, ainda, outra questão polêmica no que tange à clonagem reprodutiva, que é a definição das relações de parentesco do clone. Nesse sentido, o ser clonado seria pai ou mãe do clone? Ou ambos seriam irmãos, como os gêmeos univitelinos? No caso de irmandade, paternidade ou maternidade, os problemas na ordem sucessória seriam diferentes. Além das conseqüências jurídicas de família e sucessões, haveria divergências em relação ao registro civil do indivíduo clone ${ }^{(30)}$.

Barroso entende que inexiste violação dos direitos à vida e à dignidade da pessoa humana. Esse autor defende que o argumento contrário à utilização de células-tronco, em pesquisas e em tratamentos médicos, é nutrido por sentimentos religiosos. Argumenta ele que não há violação do direito à

(28) "Art. 26. Realizar clonagem humana: Pena - reclusão, de 2 (dois) a 5 (cinco) anos, e multa". (29) "Art. 69. Considera-se infração administrativa toda ação ou omissão que viole as normas previstas na Lei n. 11.105, de 2005, e neste Decreto e demais disposições legais pertinentes, em especial: [...] XII — realizar clonagem humana"; [...].

(30) AMARAL, Luciana. Clonagem humana. Revista Jurídica Consulex, São Paulo: n. 120, p. 13, jan. 2002. 
vida, pois o embrião obtido da fertilização in vitro, conservado em laboratório não é uma pessoa, pelo fato de não ter nascido, e não é nascituro, porque não foi transferido para o útero da mãe $e^{(31)}$.

Além disso, aplicando-se, analogicamente, o conceito de morte encefálica, se a vida se extingue quando o sistema nervoso pára de funcionar, ela teria início apenas com a formação desse sistema. Nesse mesmo sentido, inexistindo vida, não há que se falar em embrião como se pessoa fosse e, portanto, não há direito à dignidade a ser assegurado. No entanto, deve-se garantir que não haverá instrumentalização desse ser humano em potencial(32).

Nessa linha de raciocínio, a Lei de Biossegurança acertadamente encaminha-se para a admissão da clonagem com fins terapêticos, pois já possibilitou a realização de pesquisas e de tratamentos médicos apenas com embriões inviáveis, ou seja, com alterações morfológicas que comprometeriam seu desenvolvimento que, por essa razão, foi interrompido. Assim, esses embriões deixaram de ser uma vida em potencial, inclusive.

[...] A não reprodutiva poderia ser admitida desde que não se empreguem embriões pré-implantatórios, É possível o cultivo de tecidos partindo de células presentes nos órgãos do próprio paciente para, numa terapia para vítimas de acidentes ou doenças, eliminar a rejeição. Por exemplo, em Boston, no início de janeiro de 2000, houve a produção de próteses naturais de seios, mediante a multiplicação, em laboratório, de células extraídas do próprio corpo da mulher, que foram colocadas sobre um molde de plástico em formato de seio, onde se dividiram até cobri-lo. ${ }^{(33)}$

Dessa forma, não há por que proibir a utilização de células-troco embrionárias, isto é, a clonagem terapêutica, visto que essa técnica traria inúmeros benefícios aos portadores de enfermidades degenerativas, como o Alzheimer, Parkinson, câncer, diabetes, cegueira e para reposição de tecidos perdidos ou enfraquecidos. Isso se deve ao fato de que, com as célulastronco, a probabilidade de rejeição é menor, pois a célula é reintroduzida na pessoa que doou o núcleo da célula adulta.

É preciso lembrar, ainda, que não permitir a cura destas pessoas significa, além de todas as questões morais envolvidas no tema, uma grande perda econômica para o país. Anualmente, o Estado gasta milhões de reais em tratamentos paleativos e benefícios na área da saúde, previdência e assistência social. Afora isso, há que se considerar os lucros cessantes das

(31) BARROSO, Luís Roberto. Em defesa da vida digna: constitucionalidade e legitimidade das pesquisas com células-tronco embrionárias. In: SARMENTO, Daniel; PIOVESAN, Flávia (Coord.), op. cit., passim.

(32) Id. Ibid., p. 254-255.

(33) DINIZ, Maria Helena, op. cit., p. 513. 
pessoas da família do doente, que passam a atuar como cuidadores, e das próprias pessoas doentes, que, a depender do seu grau de comprometimento, acabam por ficar fora da população economicamente ativa(34).

É importante mencionar que, para obtenção dessas células, não há necessidade de introdução do óvulo no útero de uma mulher, pois esses tecidos são obtidos em laboratório. Portanto, esse embrião descartado não chega a constituir uma vida em potencial. Além disso, a utilização de células-tronco do próprio indivíduo adulto, ao invés de células embrionárias, não é tão eficaz, pois ela não possui a capacidade de se diferenciar em qualquer tecido do organismo humano como as embrionárias, que são células totipotentes ou pluripotentes - podem-se diferenciar em qualquer um dos 216 tecidos do corpo humano. Já as células de um indivíduo adulto são oligopotentes ou unipotentes, as quais podem-se diferenciar em poucos dos tecidos humanos.

Entre nós, Fermin Roland Schramm entende que há dois pontos de vista a serem considerados para enfrentar as "promessas trazidas pela clonagem humana": o ponto de vista sanitário e o ponto de vista da bioética laica. Esclarece que, sob o ponto de vista sanitário, busca-se "proteger os indivíduos e as populações das formas de adoecimento desnecessárias, por meio de políticas públicas de prevenção da doença e promoção da saúde, que sejam compatíveis com as condições objetivas existentes e com uma correta ponderação dos riscos prováveis". Portanto, respeitadas que sejam a biossegurança, a justiça distributiva e a autodeterminação pessoal, a clonagem humana pode, em princípio, fazer parte dessas políticas ${ }^{(35)}$.

Entretanto, com relação à clonagem reprodutiva, não há como permitir sua realização no Brasil, tendo em vista a necessidade de se assegurarem os direitos fundamentais consagrados na Constituição Federal, especialmente, os direitos à integridade, à identidade e à dignidade da pessoa humana, assim como a diversidade biológica do País.

No entanto, deve-se admitir que não há como travar a evolução na área biomédica. Torna-se necessário, assim, orientá-la de modo que traga mais benefícios aos seres humanos do que riscos. Portanto, a pesquisa na área genética, deve ser voltada exclusivamente para o bem da humanidade, com respeito à identidade, à saúde e à dignidade da pessoa humana, bem como à diversidade genética.

O século XXI traz consigo o receio de que o homem, ao "brincar de Deus", venha a concretizar sua ambição de se tornar o senhor da criação da vida, produzindo clones humanos, trazendo drásticas mudanças aos relacionamentos sociais e familiares e dando origem a novas demandas judiciais, de difícil solução(36).

(34) DINIZ, Maria Helena. op. cit., p. 514.

(35) BARBOZA, Heloisa Helena. op. cit.,p. 190.

(36) DINIZ, Maria Helena. op. cit., p. 540. 
Nesse caso, seria necessária a edição de leis para regular essas novas relações e os conflitos sociais e familiares, bem como para fundamentar demandas que se apresentassem perante o Poder Judiciário. No entanto, caso não forem elaborados textos legislativos que solucionem esses litígios entre clones e indivíduos clonados, os magistrados deveriam socorrer-se dos costumes, da analogia e dos princípios gerais de direito para tanto, com base no art. 4ํ da Lei de Introdução ao Código Civil - LICC ${ }^{(37)}$.

Fácil é notar que as normas existentes ficariam defasadas diante dessa nova realidade. Isso é desafiador, pois, se a clonagem humana houver, no direito surgirá "um admirável mundo novo" na determinação da paternidade, da maternidade e das relações de parentesco, na identificação de criminosos, no estabelecimento dos direitos sucessórios, na configuração dos registros públicos etc. Imprescindível seria não só a edição de normas que impedissem a clonação humana, mas também que a comunidade médica parasse com as intervenções artificiais na geração de vida humana, em laboratório, antes que seja tarde demais. Só se houver necessidade de regulamentação é que ela deverá ocorrer. Por certo, a legislação relativa aos direitos e obrigações dos clones e clonados só deveria existir quando tivermos as clonagens humanas e as primeiras demandas processuais entre clones $^{(38)}$.

Ante o exposto, verifica-se que não há possibilidade de aplicação do Processo Bokanovsky no Brasil, principalmente, porque esse procedimento visa à criação em massa de seres humanos, com a mesma carga genética, isto é, clones, cópias uns dos outros, o que não é permitido pela Carta Magna e pela legislação infraconstitucional brasileira. E mais: a implementação de um Processo Bokanovsky ou algo semelhante pode condenar o ser humano a viver em uma espécie de Admirável Mundo Novo tal qual na obra de Aldous Huxley.

\section{CONSIDERAÇÕES FINAIS}

O estudo das relações entre o Direito e a Literatura surgiu em reação ao distanciamento temporal da ciência jurídica com a sociedade e as demais ciências. Essa forma diferenciada de análise do Direito pretende a redução do fulcro positivista presente no pensamento dos juristas, ou seja, busca a afirmação de que o Direito não se resume à legislação em vigor, ao contrário, relaciona-se com a sociedade e as demais ciências e por elas é influenciado.

Cabe mencionar que a obra literária analisada no presente estudo é um exemplo da abordagem de problemas jurídicos em produções da Litera-

(37) Art. 4․․ Quando a lei for omissa, o juiz decidirá o caso de acordo com a analogia, os costumes e os princípios gerais de direito.

(38) DINIZ, Maria Helena, op. cit., p. 541. 
tura, uma vez que o autor Aldous Huxley, no livro "Admirável Mundo Novo", descreve uma sociedade estável, segura e ideal, atingida graças a avançadas tecnologias sanitárias que possibilitaram a padronização de condutas e, portanto, estabilidade, segurança e respeito às leis.

Nesse sentido, ao longo da história, o autor desenvolve diversos temas relacionados ao Direito, tais como a segurança jurídica, a inobservância da igualdade e a dignidade da pessoa humana. Tal fato ocorre em razão da divisão de toda a sociedade em classes sociais inferiores e superiores, bem como o controle do Estado sobre todos os aspectos da vida social da população e, principalmente, a produção em massa de seres humanos, mediante técnicas de clonagem, isto é, por meio do Processo Bokanovsky.

Nesse sentido, verifica-se que a escolha da obra "Admirável Mundo Novo", de Aldous Huxley - escritor inglês que desenvolveu diversas questões sociais em suas produções literárias - demonstra de modo eficaz as relações existentes entre o Direito e a Literatura, bem como as possíveis conseqüências que a adoção de técnicas de clonagem humana podem acarretar à sociedade atual e/ou futura.

Com efeito, a problemática jurídica no que tange à (im)possibilidade da clonagem humana frente às legislações é das mais atuais. Nesse sentido, analisando-se o procedimento do Processo Bokanovsky, verifica-se que o mesmo possui pontos em comum com algumas técnicas de clonagem empregadas atualmente. O Processo Bokanovsy era o principal instrumento que garantia a estabilidade social no "Admirável Mundo Novo", de Aldous Huxley. Por meio desse procedimento, as pessoas eram produzidas em laboratório, divididas em castas sociais e geneticamente idênticas umas às outras.

Assim, é importante destacar que o cerne do debate acerca da (im)possibilidade da clonagem de seres humanos no Brasil envolve questões bioéticas e jurídicas, especialmente em face do direito à identidade, à dignidade da pessoa e à diversidade biológica do País, em contraponto ao direito à reprodução e da acelerada evolução na área da biotecnologia, no caso da clonagem reprodutiva. Já a clonagem terapêutica coloca em conflito o direito fundamental à vida (em virtude do descarte do embrião para obtenção de células-tronco) e o direito à saúde (de pessoas portadoras de enfermidades neuromusculares).

No Brasil, com a promulgação da Lei n. 11.105, de 24 de março de 2005, denominada Lei de Biossegurança, o assunto passou a ser tratado de maneira expressa, sendo que o art. 6으, inciso IV, dessa Lei, proíbe a realização da clonagem humana, o que também não é permitido diante dos princípios bioéticos e constitucionais à dignidade da pessoa humana, à vida, à integridade física e moral, à saúde, bem como à preservação da diversidade e integridade do patrimônio genético do País. 
Nesse sentido, a Lei de Biossegurança, em seu art. 5o, autorizou apenas a realização de pesquisa e terapia com células-tronco embrionárias, ou seja, encaminha-se para a permissão da realização de clonagem com fins terapêuticos, a qual possibilita o tratamento de doenças como a diabetes, o Mal de Parkinson, o Alzheimer, dentre outras doenças degenerativas e neurológicas. A utilização de embriões excedentários de técnicas de fertilização in vitro é a garantia de que o direito à vida dos embriões não será violado, uma vez que a realização de pesquisas e de tratamentos médicos pode ser realizada apenas com embriões inviáveis, ou seja, com alterações morfológicas que comprometeriam seu desenvolvimento que, por essa razão, foi interrompido. Assim, esses embriões deixaram de ser uma vida em potencial, inclusive. Por outro lado, garante o direito à saúde de pessoas portadoras de doenças até então incuráveis.

Já a realização de clonagem reprodutiva não é permitida pelo ordenamento jurídico brasileiro, seja em razão dos princípios constitucionais já mencionados, seja em função de princípios bioéticos, seja pelo disposto no art. 6º inciso IV, da Lei de Biossegurança. Nesse ponto, acertou a legislação brasileira, uma vez que a aplicação de técnicas como o Processo Bokanovsy condenaria o ser humano a viver em um Admirável Mundo Novo.

\section{REFERÊNCIAS BIBLIOGRÁFICAS}

AMARAL, Luciana. Clonagem humana. Revista Jurídica Consulex, São Paulo: n. 120, p.10-15, jan. 2002.

BARBAS, Stela Marcos de Almeida Neves. Direito ao patrimônio genético. Coimbra: Almedina, 1998.

BARBOSA, Heloisa Helena. Clonagem Humana: uma questão em aberto. In: SARMENTO, Daniel; PIOVESAN, Flávia (Coord.). Nos limites da vida: aborto, clonagem humana e eutanásia sob a perspectiva dos direitos humanos. Rio de Janeiro: Lumen Juris, 2007. p. 185-207.

BARROSO, Luís Roberto. Em defesa da vida digna: constitucionalidade e legitimidade das pesquisas com células-tronco embrionárias. In: SARMENTO, Daniel; PIOVESAN, Flávia (Coord.). Nos limites da vida: aborto, clonagem humana e eutanásia sob a perspectiva dos direitos humanos. Rio de Janeiro: Lumen Juris, 2007. p. 241-263.

BRASIL. Constituição, 1988. Constituição da República Federativa Brasil de 05 de outubro de 1988. Porto Alegre: Verbo Jurídico, 2006.

. Lei n. 11.105, de 24 de março de 2005. Regulamenta os incisos II, IV e V do $\S 1^{\circ}$ do art. 225 da Constituição Federal, dispõe sobre a Política Nacional de Biossegurança - PNB. Presidência da República. Legislação Republi- 
cana Brasileira. Brasília, 2005. Disponível em: <http://www.planalto.gov.br/ccivil_03/_Ato2004-2006/2005/Lei/L11105.htm>. Acesso em: 23 set. 2007.

BRASIL. Decreto n. 5.591, de 22 de novembro de 2005. Regulamenta dispositivos da Lei n. 11.105, de 24 de março de 2005. Presidência da República. Legislação Republicana Brasileira. Brasília, 2005. Disponível em: <http:// www.planalto.gov.br/ccivil_03/_Ato2004-2006/2005/Decreto/D5591.htm>. Acesso em: 23 set. 2007.

DINIZ, Maria Helena. O Estado atual do biodireito. 3. ed. São Paulo: Saraiva, 2006.

ENCICLOPÉDIA Barsa. Ciência e futuro 2004. São Paulo: Barsa Planeta Internacional, 2004.

HUXLEY, Aldous. Admirável mundo novo. 2. ed. São Paulo: Globo, 2003.

PEREIRA, Lygia da Veiga. Clonagem: fatos \& mitos. São Paulo: Moderna, 2002.

PESSINI, Leo; BARCHIFONTAINE, Christian de Paul de. Problemas atuais de bioética. 6. ed. São Paulo: Loyola, 2002.

RODRIGUES, Hugo Thamir. A aplicação dos princípios da bioética nas técnicas de reprodução medicamente assistida. In: RODRIGUES, Hugo Thamir. (Coord.). Direito constitucional \& políticas públicas. Porto Alegre: Imprensa Livre, 2005.

SÁ, Maria de Fátima Freire de; NAVES, Bruno Torquato de Oliveira. Clonagem humana. In: SARMENTO, Daniel; PIOVESAN, Flávia (Coord.). Nos limites da vida: aborto, clonagem humana e eutanásia sob a perspectiva dos direitos humanos. Rio de Janeiro: Lumen Juris, 2007. p. 265-275.

SARLET, Ingo Wolfgang. A eficácia dos direitos fundamentais. 2. ed. Porto Alegre: Ed. Livraria do Advogado, 2001.

SCHWARTZ, Germano. Direito à saúde: efetivação em uma perspectiva sistêmica. Porto Alegre: Livraria do Advogado, 2001.

Um admirável novo direito: autopoiese, risco e altas tecnologias sanitárias. [S.I.:s.n.], 2006.

SÉGUIN, Elida. Biodireito. 4. ed. rev. e atual. Rio de Janeiro: Lumen Juris, 2005. 